\title{
To Our Contributors
}

Guidelines for submissions:

1. All copy should be typed double-spaced, including between and within footnotes. Allow approximately a one-inch margin on all four sides of the page.

2. Articles should be no more than 35 pages including endnotes; (or, no more than 9,000 words).

3. Article font should be 10 characters per inch (or pica type).

4. Four copies of the manuscript should be submitted on white paper, addressed to the History of Education Quarterly, College of Education, Slippery Rock University, Slippery Rock, PA 16057-1326. Manuscripts are not returned unless a self-addressed envelope with sufficient postage accompanies the article.

5. The author's name should appear only on the title page of the article.

6. Footnotes should be listed in a separate section at the end of the article. The following formats should be used for references:

Book:

${ }^{1}$ Lawrence A. Cremin, Transformation of the School: Progressivism in American Education, 1876-1957 (New York: Vintage Books, 1964), 25.

Edited Book:

${ }^{2}$ Linda M. Perkins, "The History of Blacks in Teaching: Growth and Decline Within the Profession," in American Teachers: Histories of a Profession at Work, ed. Donald Warren (New York: MacMillan Publishing Co., 1989), 351.

Fournal Article:

${ }^{3}$ Guadalupe San Miguel, Jr., "The Struggle Against Separate and Unequal Schools: Middle-Class Mexican Americans and the Desegregation Campaign in Texas, 1929-1956," History of Education Quarterly 23 (Fall 1983): 343-359.

Popular Magazine Article:

${ }^{4}$ W. Caspari and R. E. Marshak, "The Rise and Fall of Lysenko," Science, 16 Aug. 1965, 275-78.

Unpublished Work:

${ }^{5}$ Marjorie Murphy, "From Artisan to Semi-Professional: White-Collar Unionism among Chicago Public School Teachers, 1870-1930," (Ph.D. diss., University of California-Davis, 1981), 106.

Manuscript:

${ }^{6}$ Hiram Johnson to John Callan O'Laughlin, 16 July 1916, file 6, box 20, O'Laughlin Papers, Roosevelt Memorial Collection, Harvard College Library.

Second and subsequent references:

${ }^{7}$ Cremin, Transformation of the School, 320.

${ }^{8}$ San Miguel, Jr., "Struggle Against Separate and Unequal Schools," 350.

The style of the History of Education Quarterly conforms very closely to The Cbicago Manual of Style, 14th ed. (Chicago, 1993). Authors should consult this manual if they have further questions. 
Topics span the history of education, both formal and nonformal, including the history of childhood, youth, and the family. These subjects are not limited to any time period and are universal in scope. The Quarterly is published in cooperation with the College of Education, Slippery Rock University of Pennsylvania.

\section{The History of Education Society}

Individual subscription to the Quarterly includes membership in the History of Education Society. The Society is an international organization that seeks to encourage research in the history of education, to improve the teaching of history of education, to promote the preservation of source materials in history of education, and to interest the educational profession and the general public in the value of the historical perspective in the making of educational policy.

Subscription rates (per calendar year only):

$\begin{array}{lll} & \text { US } & \text { Non-US } \\ \text { Individual (Non-Student) } & \$ 40 & \$ 47 \\ \text { Student } & \$ 20 & \$ 27 \\ \text { Institutions } & \$ 77 & \$ 84\end{array}$

Please address all subscription orders to

HISTORY OF EDUCATION QUARTERLY

220 McKay Education Building

College of Education

Slippery Rock University

Slippery Rock, PA 16057-1326 
